\title{
Genetic Regulation of Glycogen Biosynthesis in Escherichia coli: In Vivo Effects of the Catabolite Repression and Stringent Response Systems in $g l g$ Gene Expression
}

\author{
Tony Romeo, ${ }^{1}$ Jill Black, ${ }^{2}$ and Jack Preiss \\ Department of Biochemistry, Michigan State University, East Lansing, Michigan, USA
}

\begin{abstract}
The synthesis of two of the Escherichia coli glycogen biosynthetic enzymes, ADPglucose pyrophosphorylase $(\mathrm{glgC})$ and glycogen synthase $(\mathrm{glg} \mathrm{A})$ was activated by the addition of $5 \mathrm{~m} M$ cyclic AMP (cAMP) to maxicells; synthesis of glycogen branching enzyme $(\mathrm{glg} \mathrm{B}$ ) was unaffected. $\beta$-Galactosidase activity expressed from a gene fusion, $\phi(\mathrm{glgC}-\mathrm{lac} \mathrm{Z})$, was approximately five-fold higher in a $c y a^{+}$versus an isogenic $c y a^{-}$strain of $E$. coli. Addition of cAMP restored $\beta$-galactosidase in the $c y a^{-}$strain. The expression of $\phi\left(g \lg \mathrm{C}^{\prime}-{ }^{\prime} l a c \mathrm{Z}\right)$ encoded $\beta$ galactosidase activity in a series of spoT mutants exhibited an apparent exponential relationship to intracellular guanosine 5'-diphosphate $3^{\prime}$-diphosphate (ppGpp) levels. These results provide evidence for the control of glycogen biosynthesis in vivo by cAMP and ppGpp at the level of gene expression, and identify a region of DNA required for the control. The $\phi\left(g \lg \mathrm{C}^{\prime}-{ }^{\prime} \operatorname{lac} \mathrm{Z}\right)$ encoded $\beta$-galactosidase activity was also elevated three- to five-fold in strain AC70R1, which contains a transacting mutation $(g \lg Q)$ that affects the levels of the glycogen biosynthetic enzymes and $g l g \mathrm{C}$ transcripts.
\end{abstract}

The rate of glycogen biosynthesis in Escherichia coli is inversely related to nutrient availability and to the growth rate [reviewed in 9]. Thus, a complex of various controls are most likely required to coordinate the synthesis of glycogen to the physiological state of the culture. At least two levels of control are involved. The first step of the biosynthetic pathway is catalyzed by ADP glucose pyrophosphorylase, and a considerable body of information has shown that this step is controlled allosterically in response to intracellular metabolite levels [9]. In addition, the observed variations in the intracellular levels of the three biosynthetic enzymes suggest regulation at the level of gene expression [9-12]. Recent studies with coupled transcription-translation assays in S-30 extracts indicated that the expression of $g \operatorname{lgC}$ (ADP glucose pyrophosphorylase) and $g \lg \mathrm{A}$ (glycogen synthase) is under positive control of

\footnotetext{
${ }^{1}$ Current Address: Department of Microbiology and Immunology, Texas College of Osteopathic Medicine, Fort Worth, TX 76107-2690, USA.

${ }^{2}$ Current Address: Department of Pharmacology, University of Michigan, Ann Arbor, MI 48104, USA.
}

cAMP and ppGpp [15]. The expression of the $\operatorname{glg} \mathrm{B}$ gene (glycogen branching enzyme) was unaffected by either compound and was proposed to reside in an operon separate from $g \lg \mathrm{C}$ and $g \lg \mathrm{A}$. In the presence of cAMP receptor protein (CRP), cAMP was also effective in stimulating the expression of $g \lg \mathrm{C}$ and $g \lg \mathrm{A}$ in a compositionally defined assay, which measures the formation of the first dipeptide of specific gene products $[15,20]$. Although the effects of ppGpp were reproducibly observed with S-30 extracts, no significant effects were observed under the conditions of the dipeptide synthesis assay, and it was suggested that one or more additional factors may mediate the effect $[15,20]$.

The present studies were designed to measure the effects of the catabolite repression system and the stringent response system on the expression of the glycogen biosynthetic genes in vivo and to delineate the region of DNA in the $\mathrm{glg}$ gene cluster that contains the cis-acting control sites for regulation. The effects of cAMP on $g \lg \mathrm{C}, g \lg \mathrm{A}$, and $g \lg \mathrm{B}$ were determined in a maxicell expression assay system. The 5 '-flanking region of $g \operatorname{lgC}$ was subcloned into pMLB1034 and $\beta$-galactosidase activity expressed 
from the resulting $\mathrm{glg} \mathrm{C}^{\prime}-\operatorname{lac} \mathrm{Z}$ gene fusion was assessed in mutant strains of $E$. coli. The results of these studies support observations made with the S-30 assay and indicate that both cAMP and ppGpp regulate expression of the $g l g \mathrm{C}$ gene. Evidence is presented to suggest that the previously identified glg Q mutation does not affect catabolite repression or stringent response, and therefore identifies a third system that regulates $g l g$ gene expression.

\section{Materials and Methods}

Chemicals and reagents. The $\left[{ }^{35} \mathrm{~S}\right] \mathrm{methionine}(1.4 \mathrm{mCi} / \mu \mathrm{mol})$ was purchased from Amersham Corp. (Arlington Heights, Illinois). The cAMP, IPTG (isopropyl- $\beta$-D-thiogalactopyranoside), antibiotics, and ONPG (o-nitrophenyl- $\beta$-D-galactopyranoside) were from Sigma Chemical Co., (St. Louis, Missouri). Enzymes for DNA manipulation and analysis were from sources previously indicated $[13,14]$. Water was deionized and purified through a MilliQ system (Millipore Corp., Bedford, Massachusetts) prior to use.

Bacterial strains and media. The strains used in these studies included wild type $E$. coli B and $E$. coli B AC70R1 (glgQ) [9], CF747 (pyrG ${ }^{+}$rec $\mathrm{A} 1$ thi-1 pyrE60 arg E3 his-4 pro A2 thr-1 leu $\mathrm{B} 6$ mtl-1 ryl-5 ara-14 galK2 lacY1 rpsL31 sup E44 cdd gyrA(Na1) relA1入-spoT ${ }^{+}$), CF954-956 (rec A56 srl-300::Tn10 pyrE $\mathrm{E}^{+} \mathrm{his}^{+}$ pyr $\mathrm{G}^{+}$thi-1 arg E3 proA2 thr-1 leuB6 $\mathrm{Mtl}-1$ xyl-5 ara-14 galK2 lac $\mathrm{Y} 1$ rps L31 sup E44 cdd gyr A(Na1) rel A 1 ג-spo T202-204) [18], ML2 (met gal,hsdkR sup E sup F Km $\Delta c y a$ ) [3], and ED8654 (met gal hsdk $\mathrm{R}$ sup $\mathrm{E}$ sup F) [3], MBM7060 (F- ara C am $\operatorname{araD}(\arg \mathrm{F}-$ lac) $\mathrm{U} 169$ trp am malB am rps $\mathrm{L}$ rel A thi sup $\mathrm{F}$ ( $\lambda \mathrm{p}$ 1048)) [19], $\mathrm{HB} 101\left(\mathrm{Fp} h s d \mathrm{~S} 20\left(\mathrm{r}_{\mathrm{B}}-\mathrm{m}_{\mathrm{B}}-\right)\right.$ rec $\mathrm{A} 13$ ara-14 pro $\mathrm{A} 2$ lac $\mathrm{Y} 1$ gal 2

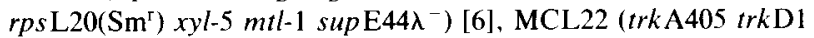
thi $\Delta(k d p-p h r) 214$ rha $\delta($ gal-uvrB) $\Delta($ srl-rec A) 306 rpsL31) [5]. The preparation of Kornberg medium [15] and MOPS minimal medium [18] was previously described. The M9 minimal medium contained $0.6 \% \mathrm{Na}_{2} \mathrm{HPO}_{4}, 0.3 \% \mathrm{KH}_{2} \mathrm{PO}_{4}, 0.5 \% \mathrm{NaCl}$, and $0.15 \%$ $\mathrm{NH}_{4} \mathrm{Cl}$. M9-supplemented medium is $\mathrm{M} 9$ minimal medium plus 1 $\mathrm{mM} \mathrm{MgSo}_{4}, 0.1 \mathrm{mMCaCl}, 2 \mu \mathrm{g}$ biotin $\mathrm{ml}, 1 \mu \mathrm{g}$ thiamine $\mathrm{ml}$, $0.4 \%$ casamino acids, and $0.5 \%$ glucose. M9 sulfate-free medium was M9-supplemented medium with the substitution of $\mathrm{MgCl}_{2}$ for $\mathrm{MgSO}_{4}$ and without casamino acids.

Plasmids. The plasmid pMLB1034 was previously described [19] Plasmid pOP12 contains the $E$. coli glycogen biosynthetic genes cloned into pBR322 [8]. Plasmid pOP189 is an EcoRI-generated derivative of pOP12 that lacks the $g \lg \mathrm{C}$ and $g \lg \mathrm{A}$ genes [8]. The plasmid pCZ3 was constructed by ligating a $0.7 \mathrm{KbHinclI}-\mathrm{BamHI}$ restriction fragment from pOP12 into the SmaI-BamHI site of pMLB1034, and transforming HB101 to ampicillin resistance. The plasmid $\mathrm{pCZ} 3$ was characterized by restriction endonuclease mapping and contained an out-of-frame fusion of the $g \lg \mathrm{C}$ and lac $\mathrm{Z}$ genes. A previously described in vivo method for isolating in-frame mutations of plasmid-encoded lac $Z$ gene fusions [19] was used to obtain several such plasmids. These were characterized by restriction mapping. The plasmid chosen for study, $\mathrm{pCZ3}-3$, resulted from an 8-bp deletion event which removed the single BamHI site in $\mathrm{pCZ} 3$. Codon 64 of $g l g \mathrm{C}$ is fused to codon 9 of lac Z in pCZ3-3 (T. Romeo and J. Preiss, unpublished nucleo- tide sequence data). The procedures utilized in plasmid construction were previously described $[15,16]$.

Maxicell analysis. The maxicell procedure was used for identification of plasmid-encoded proteins [17], with minor modifications suggested by Dr. M. C. Lorence (University of Texas Health Science Center at Dallas). Exponential cultures from MCL22, which had been transformed with the plasmids of interest, were grown to an absorbance of 0.60 at $450 \mathrm{~nm}$ in M9-supplemented medium containing tetracycline $(20 \mu \mathrm{g} / \mathrm{ml})$, irradiated with shortwave UV light, and mixed with an equal volume of M9-supplemented medium. Cultures were incubated at $37^{\circ} \mathrm{C}$ for $3 \mathrm{~h}$ and treated with cycloserine $(200 \mu \mathrm{g} / \mathrm{ml})$. Cultures were incubated an additional $3 \mathrm{~h}$ and treated again with cycloserine. After overnight incubation, the cultures were treated a third time with cycloserine, washed and resuspended in sulfate-free M9 medium, and incubated for $1 \mathrm{~h}$. The cultures were then split into two $2.5-\mathrm{ml}$ portions, and cAMP $(5 \mathrm{mM})$ was added to one of the portions. The cultures were incubated for $10 \mathrm{~min}$ and were labeled with $\left.{ }^{[35} \mathrm{S}\right]$ methionine $(5 \mu \mathrm{Ci} / \mathrm{ml})$ for $1 \mathrm{~h}$. Cells were washed with M9 minimal medium, suspended in lysis buffer $(0.125 M$ Tris, $\mathrm{pH} 6.8$, $4 \%$ SDS, $20 \%$ glycerol, $10 \% 2$-mercaptoethanol), and heated for $2 \mathrm{~min}$ at $100^{\circ} \mathrm{C}$. Equal volumes of cell proteins $(20 \mu \mathrm{L}$ from 100 $\mu \mathrm{L}$ of cell extract) were analyzed in $10 \%$ SDS polyacrylamide slab gels with the buffer system of Laemmli [4]. The gels were stained with Coomassie blue, and labeled proteins were visualized by fluorography, as described [15].

$\boldsymbol{\beta}$-galactosidase assays. Assays were carried out according to Miller [7] with minor modification. Bacterial cultures were grown in either MOPS minimal medium or Kornberg medium containing $0.2 \%$ glucose and $100 \mu \mathrm{g} / \mathrm{ml}$ ampicillin at $37^{\circ} \mathrm{C}$ with gyratory shaking at $200 \mathrm{rpm}$. For enzyme assays, $0.125 \mathrm{ml}$ of culture was added to $0.5 \mathrm{ml}$ of $0.1 \mathrm{M}$ sodium phosphate buffer, $\mathrm{pH}$ 7.0, containing $0.2 \mathrm{M} \mathrm{KCl}, 0.002 \mathrm{M} \mathrm{MgSO}_{4}, 0.1 \mathrm{M}$ 2-mercaptoethanol, and $100 \mu \mathrm{g} / \mathrm{ml}$ chloramphenicol. This was followed by addition of $0.25 \mathrm{ml}$ of $300 \mu \mathrm{g} / \mathrm{ml}$ sodium deoxycholate and one drop of toluene. The reactions were shaken at $37^{\circ} \mathrm{C}$ for $30 \mathrm{~min}$, cooled to room temperature, and $0.25 \mathrm{ml}$ of $13.3 \mathrm{mM} o$-nitrophenyl $\beta$-D-galactopyranoside (ONPG) or water (for no substrate blanks) was added. The enzymatic reactions were allowed to proceed for $10 \mathrm{~min}$ at $22^{\circ} \mathrm{C}$ and were stopped by the addition of $1 \mathrm{~N} \mathrm{~K}_{2} \mathrm{CO}_{3}$. The reactions were subjected to centrifugation to eliminate turbidity, and absorbance of each reaction was determined at $420 \mathrm{~nm}$, relative to an identical blank reaction that lacked ONPG. In order to correct for differences in cell mass of the cultures during these experiments, the enzyme activity $\left(A_{420}\right)$ was normalized relative to cell mass $\left(A_{600}\right)$. In order to calculate $\beta$ galactosidase expressed from $\phi\left(g l g \mathrm{C}^{\prime}-\operatorname{lac} \mathrm{Z}\right)$, the uninduced $\mathrm{ex}$ pression from the chromosomal copy of lac $Z$ was estimated by measuring $\beta$-galactosidase activity from strains containing pMLV1034 and was subtracted from the activity from pCZ3-3containing strains. Although the large number of samples required for these studies prohibited the determination of more than a single experimental value for each time point, each of the growth curve experiments has been conducted at least twice, with similar results.

\section{Results}

Effects of cAMP on the expression of $\boldsymbol{g l g}$ genes in maxicells. The maxicell technique was used in order 


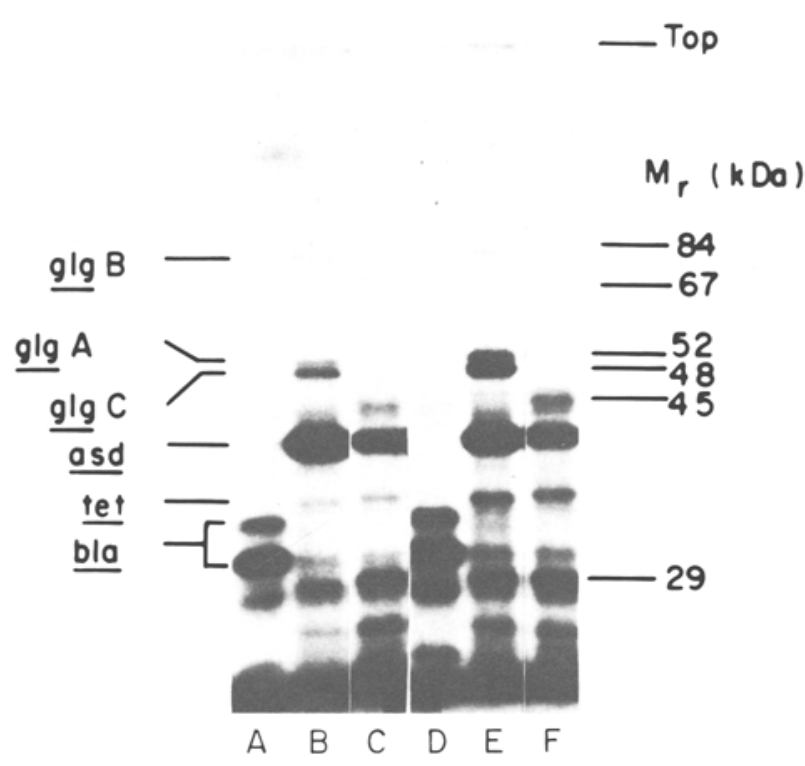

Fig. 1, Expression of glg genes in maxicells. Plasmid-encoded proteins synthesized by $E$, coli MCL22 were analyzed by the maxicell procedure, as described in Materials and Methods. Fluorographic analysis of $\left[{ }^{35} \mathrm{~S}\right]$ methionine-labeled proteins from cells containing pBR322, lanes $A$ and $D ;$ pOP12, lanes $B$ and $E$; and pOP189, lanes $\mathrm{C}$ and $\mathrm{F}$, are shown. CAMP $(5 \mathrm{mM})$ was added to cultures shown in lanes $\mathrm{D}, \mathrm{E}$, and $\mathrm{F}$. The bands corresponding to the labeled products of $g \lg \mathrm{B}, g \lg \mathrm{C}$, and $g \lg \mathrm{A}$ were identified by comparison with purified standards of glycogen branching enzyme, $85 \mathrm{kDa}$; ADP glucose pyrophosphorylase, $48 \mathrm{kDa}$; and glycogen synthase, $52 \mathrm{kDa}$, respectively. The other labeled products of asd, tet, and bla were identified by comparison of their mobilities with those of the above marker proteins and the mobilities of bovine serum albumin, $67 \mathrm{kDa}$; ovalbumin, $45 \mathrm{kDa}$; and carbonic anhydrase, $29 \mathrm{kDa}$.

to examine the effect of exogenous cAMP on the in vivo expression of the glycogen biosynthetic genes. Figure 1 shows that several plasmid-encoded proteins were synthesized in strain MCL22[pOP12] but not in MCL22[pBR322]. The overall pattern was similar to that of the proteins expressed in vitro from pOP12 [16]. The three largest labeled proteins were identical in electrophoretic mobility with purified standards of ADPglucose pyrophosphorylase (49 $\mathrm{kDa})$, glycogen synthase $(52 \mathrm{kDa})$, and glycogen branching enzyme $(84 \mathrm{kDa})$. Further information on the identity of these three proteins was obtained with strain MCL22[pOP189]. Plasmic pOP189 is a deletion derivative of pOP12 and lacks part of the $g \lg \mathrm{C}$ gene and all of the $g \lg \mathrm{A}$. Therefore, this plasmid does not encode ADP glucose pyrophosphorylase and glycogen synthase activities [8]. The in vivo labeled proteins from MCL22[pOP189] no longer include those presumed to be ADP glucose pyrophosphorylase and glycogen synthase [Fig. 1, lanes C
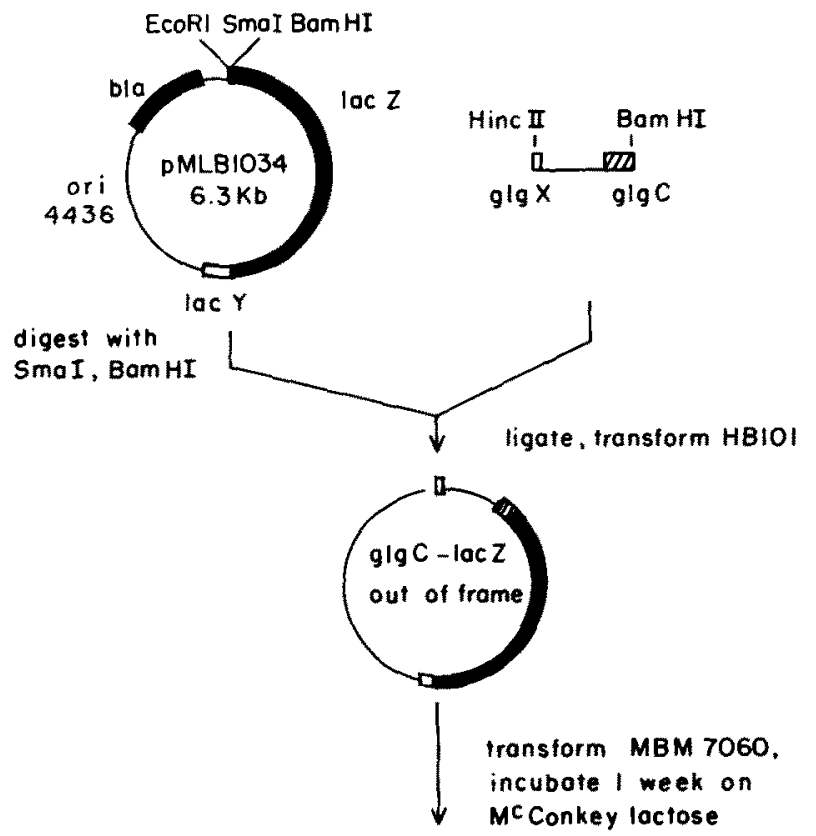

isolate pink colonies, isolate and characterize in frome $\mathrm{glg} \mathrm{C}-\operatorname{loc} \mathrm{Z}$ fusion plosmids

Fig. 2. Construction of an in-frame $g \lg \mathrm{C}^{\prime}-\operatorname{lac} \mathrm{Z}$ gene fusion.

and F). The addition of $5 \mathrm{~m} M$ cAMP to maxicells resulted in a significant increase in the incorporation of $\left[{ }^{35} \mathrm{~S}\right]$ into ADP glucose pyrophosphorylase and glycogen synthase [Fig. 1, lane E]. The synthesis of glycogen branching enzyme showed little or no effect upon addition of cAMP. This suggested that the effect of cAMP was at the level of $g l g \mathrm{C}$ and $g l g \mathrm{~A}$ gene expression, and was not owing to nonspecific effects such as alteration of the intracellular methionine pool.

Expression of a $\operatorname{lac} Z$ gene fusion under the $g l g C$ regulatory controls. In order to simplify the examination of the effects of ppGpp and other trans-acting regulatory factors on in vivo expression of the glycogen genes, we constructed a plasmid-encoded lac $\mathrm{Z}$ gene fusion [Fig. 2]. The plasmid pCZ3-3 contains $0.5 \mathrm{~kb}$ of DNA flanking the $5^{\prime}$ end of $g \operatorname{lgC}$ and 64 codons of the $g \operatorname{lgC}$ gene fused to codon 9 of $\operatorname{lac} \mathrm{Z}$ (unpublished nucleotide sequence analysis, T. Romeo and J. Preiss). Transformation of appropriate strains with pCZ3-3 allowed the use of $\beta$-galactosidase activity as an assay for the effects of transacting mutations on the expression of glgC. A lacZstrain of E. coli, MBM7060, was transformed with 
Table 1. $\beta$-Galactosidase levels in MBM7060 ${ }^{a}$

\begin{tabular}{rcclcc}
\hline & \multicolumn{2}{c}{$\mathrm{pCZ3-3}$} & & \multicolumn{2}{c}{$\mathrm{pMLB1034}$} \\
\cline { 2 - 3 } \cline { 5 - 6 } TIME (h) & - IPTG & + IPTG & & - IPTG & + ITPG \\
\hline 2.0 & 0.023 & 0.057 & & 0.000 & 0.000 \\
4.8 & 0.085 & 0.090 & & 0.007 & 0.018 \\
18.0 & 0.230 & 0.217 & & 0.006 & 0.010 \\
\hline
\end{tabular}

${ }^{a}$ Values are expressed as $\beta$-galactosidase activity/cell mass $\left(A_{420} / A_{600}\right)$.

pMLB1034 and pCZ3-3, and $\beta$-galactosidase activity was measured in both transformants. Table 1 shows that (i) no $\beta$-galactosidase activity was expressed from pMLB1034, which lacks the $g \lg$ C DNA; (ii) the expression of $\beta$-galactosidase from pCZ3-3 is not affected by IPTG, the gratuitous inducer of the native lac $\mathrm{Z}$ gene; and (iii) pCZ3-3-encoded activity is elevated in stationary phase, as would be expected if the expression of $\beta$-galactosidase is under $g \operatorname{lgC}$ regulatory control.

In order to examine the effect of cAMP on $g \operatorname{lgC}$ expression, isogenic strains ED8654 $\left(\mathrm{cya}^{+}\right)$and ML2 ( $\triangle$ cya) were transformed with pCZ3-3, and pCZ3-3-encoded $\beta$-galactosidase activity was determined throughout the growth curve. Figure 3 shows that the growth rate of these strains was essentially identical under the conditions shown; however, the synthesis of plasmid-encoded $\beta$-galactosidase was approximately fivefold higher in ED8654 than in ML2 throughout the growth curve. The addition of $5 \mathrm{~m} M$ cAMP to the cultures resulted in a stimulation of the synthesis of plasmid-encoded $\beta$-galactosidase activity in ML2 almost to the level observed in ED8654 and resulted in an increase of activity of approximately $50 \%$ in ED8654. The growth rate of each strain was decreased to a similar extent in the presence of exogenous cAMP.

The effect of ppGpp on expression of the $g \lg \mathrm{C}^{\prime}-\operatorname{lac} \mathrm{Z}$ gene was assessed by a series of $s p o \mathrm{~T}$ mutants which were impaired to various extents in their ability to degrade endogenous ppGpp [18]. The elevated intracellular levels of $\mathrm{ppGpp}$ in these strains result in a decrease in their growth rates. The doubling times and ppGpp levels for these strains were previously shown to exhibit a linear relationship [18]. Figure 4 shows the quantitative relationship between plasmid-encoded $\beta$-galactosidase activity and growth rate of these strains. Maximal activity in these strains occurred during the early- to midexponential phase, then decreased until the cultures entered the stationary phase. Therefore, the activity

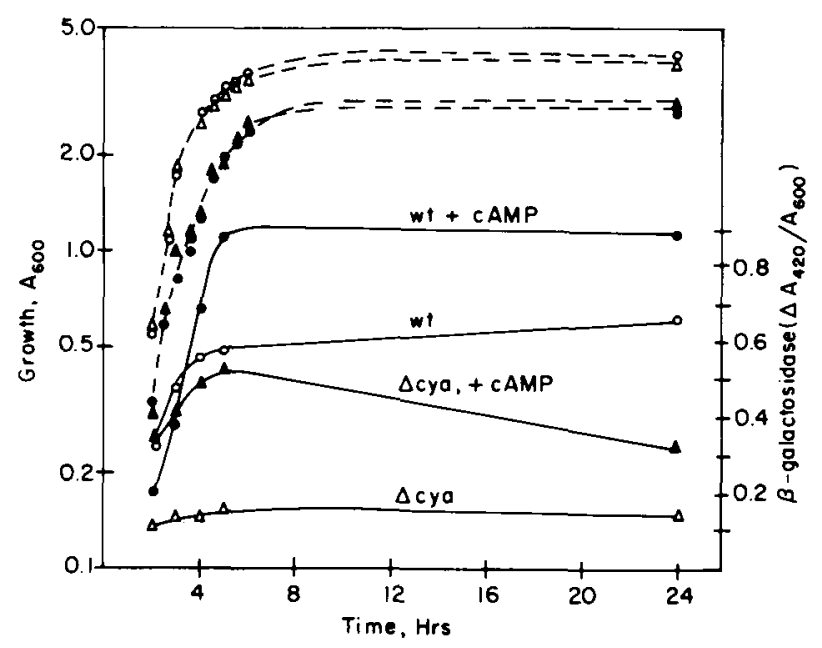

Fig. 3. Expression of pC233-encoded $\beta$-galactosidase activity in $\operatorname{ML2}(\Delta c y a)$ and ED $8654(w t)$. Cultures were grown in Kornberg medium, and assays were conducted under conditions described in Materials and Methods. Broken lines depict absorbance of cultures of $600 \mathrm{~nm}$; solid lines indicate plasmid-encoded $\beta$-galactosidase activity corrected for cell mass. Cultures of ML2 were indicated by triangles; ED8654, circles. Solid symbols indicated growth in the presence of cAMP, $5 \mathrm{mM}$.

remained almost constant. This was in contrast to the pattern observed for glycogen biosynthetic enzyme levels in many E. coli strains [8-12] and differed from the pattern of expression of $\phi\left(g \lg \mathrm{C}^{\prime}-\right.$ lacZ) in other strains [Fig. 3 and Fig. 5].

Insets $\mathrm{a}$ and $\mathrm{b}$ of Fig. 4 compare the doubling times for these strains with the plasmid-encoded $\beta$ galactosidase activity. Since the intracellular ppGpp concentrations vary in a direct linear relationship with the doubling times under the growth conditions used in these experiments [18], these results establish that an exponential relationship exists between intracellular ppGpp in these strains and the expression of $\phi\left(g \lg \mathrm{C}^{\prime}-\operatorname{lac} \mathrm{Z}\right)$. Although the copy numbers of pCZ3-3 in spoT strains were not measured, the effects of these spo T mutations on the copy number of a similar pBR322-derived plasmid were minimal [18].

A trans-acting mutation, $g \lg \mathrm{Q}$, leads to increases in the levels of the three glycogen biosynthetic enzymes (approximately tenfold for ADP glucose pyrophosphorylase and fivefold for glycogen synthase [9]) and was recently shown to affect transcription of $g \lg \mathrm{C}[15]$. The strain containing the $g \lg \mathrm{Q}$ mutation, E. coli B AC70R1, and wild type E. coli $B$ were transformed with plasmid $\mathrm{pCZ3}-3$ or pMLB 1034, and the resulting $\beta$-galactosidase activity was determined. Table 2 shows that under the 


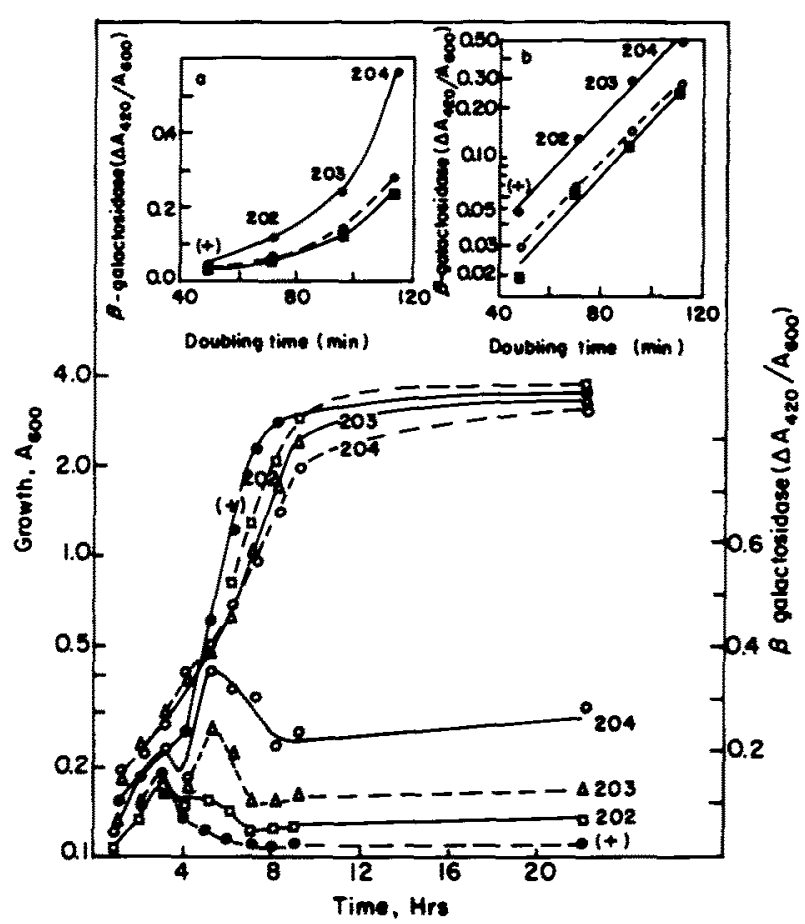

Fig. 4. Expression of pCZ3-3 encoded $\beta$-galactosidase activity in spoT strains. Cultures were grown in MOPS medium, and assays were conducted as described in the Materials and Methods. Growth was plotted as a function of time on a semilogarithmic scale, and plasmid-encoded $\beta$-galactosidase activity has been corrected for cell mass $\left(A_{600}\right)$ and plotted on a linear scale. The data are shown for CF747 (spo T ${ }^{+}$) and CV954-956 (spoT202-204) as closed circles, open squares, triangles, and open circles, respectively. Inset $a$ shows the relationship between doubling time for each strain and $\beta$-galactosidase activity plotted on a linear scale; inset $b$ shows the same relationship plotted on a semi-logarithmic scale. The enzyme activity for each strain was taken from midexponential, late exponential, or stationary phase, and is shown as closed circles, open circles, and squares, respectively.

conditions used for the growth, both $E$. coli B [pBML1034] and AC70R1[pMLB1034] synthesized similar levels of $\beta$-galactosidase. This indicated that the $g \lg \mathrm{Q}$ mutation in AC70R1 did not alter expression of the chromosomal lacZ gene. Additional experiments to compare the expression of the chromosomal lacZ gene in E. coli $\mathrm{B}$ and AC70R1 did not alter expression of the chromosomal lac Z gene. Additional experiments to compare the expression of the chromosomal lacZ gene in $E$. coli $\mathrm{B}$ and AC70R1 were carried out in minimal medium in the presence or absence of IPTG $(6.25 \mathrm{mM})$ and glucose $(0.5 \%)$. The $\beta$-galactosidase activity from these two strains differed by no more than $35 \%$ under any condition tested (data not shown). In contrast, the expression of $\phi\left(g l g \mathrm{C}^{\prime}-\operatorname{lacZ}\right)$ of $\mathrm{pCZ3-3}$ was two- to fivefold

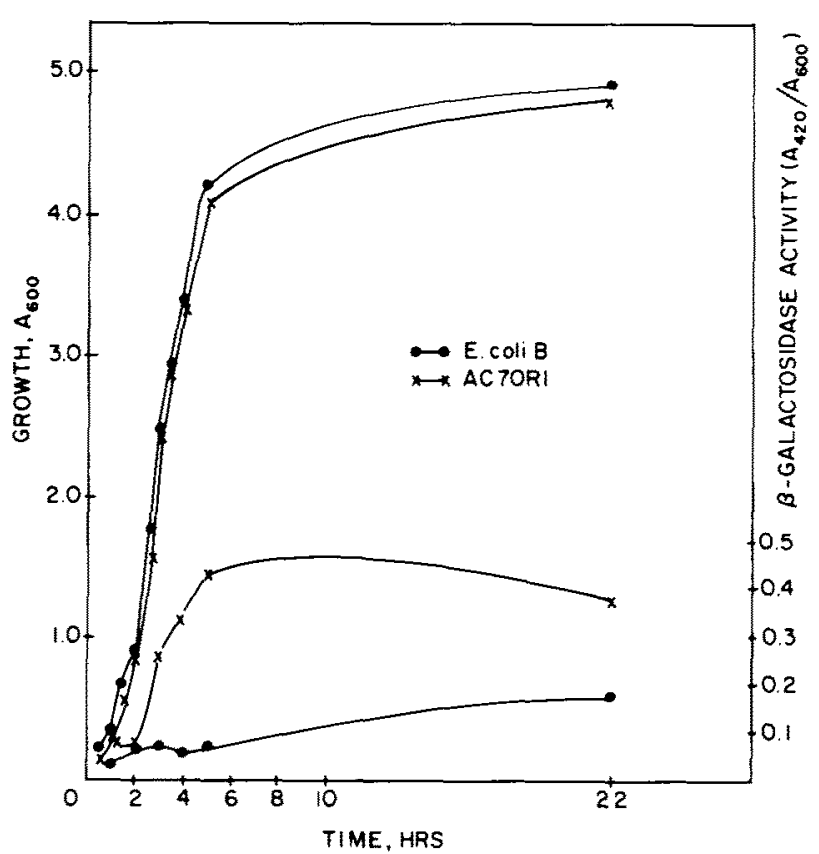

Fig. 5. Expression of pCZ3-3-encoded $\beta$-galactosidase activity in E. coli $\mathrm{B}$ and $\mathrm{AC} 70 \mathrm{R} 1$ ( $g l g \mathrm{Q})$. Cultures were grown in Kornberg medium, and assays conducted as described in Materials and Methods.

higher in AC70R1 [Table 2]. Figure 5 compares the pattern of $\phi\left(g \lg \mathrm{C}^{\prime}-{ }^{\prime} l a c \mathrm{Z}\right)$ expression through the growth curves of these strains. These results suggest that the glgQ mutation does not affect the regulatory factors responsible for the expression of the native lacZ gene, i.e. cAMP, CRP, or ppGpp. However, the glgQ mutation has a significant effect upon the expression of $\phi\left(g \lg \mathrm{C}^{\prime}-^{\prime} l a c \mathrm{Z}\right)$.

\section{Discussion}

Previous in vitro studies on the expression of genes for glycogen biosynthesis indicated that cAMP and ppGpp may function to positively alter the level of expression of $g \lg \mathrm{C}$ and $g \lg \mathrm{A}$ [15]. Evidence for regulation in the case of cAMP was particularly strong and included the observations that cAMP activated the expression of transcription-translation reactions and, in the compositionally defined dipeptide synthesis assay, that the cAMP-CRP complex was capable of binding specifically to restriction fragments from the region proximal to $\mathrm{g} \operatorname{lgC}$ [15]. However, evidence that $\mathrm{ppGpp}$ activates the expression of $\mathrm{glg}$ genes was less definitive. In particular, ppGpp did not enhance $g l g C$ expression in the dipeptide assay $[15,20]$. The results of the present study support the 
Table 2. $\beta$-Galactosidase levels in $E$. coli $\mathrm{B}$ and AC70R1

\begin{tabular}{|c|c|c|c|c|c|c|}
\hline \multirow[b]{2}{*}{ TIME (h) } & \multicolumn{2}{|c|}{ pMLB 1034} & \multicolumn{2}{|c|}{ pCZ3-3 } & \multicolumn{2}{|c|}{$\Delta^{a}$} \\
\hline & E. coli $\mathrm{B}$ & AC70R1 & E. coli $\mathrm{B}$ & AC70R 1 & E. $\operatorname{coli} \mathrm{B}$ & AC70R 1 \\
\hline 2.0 & 0.265 & 0.226 & 0.298 & 0.303 & 0.033 & 0.077 \\
\hline 3.5 & 0.172 & 0.122 & 0.251 & 0.333 & 0.079 & 0.211 \\
\hline 21.0 & 0.120 & 0.140 & 0.250 & 0.760 & 0.130 & 0.620 \\
\hline
\end{tabular}

${ }^{a} \Delta$ indicates the difference between the activities from cells conaining pCZ3-3 and pMLB1034.

conclusions obtained with the coupled transcriptiontranslation assays and indicate that ppGpp activates the expression of the $\mathrm{glg}$ genes in vivo. It was previously noted that ppGpp may require a factor that is absent from the dipeptide assay in order to alter transcription of the glg genes, or ppGpp may have effects on translation [15]. For the latter to be sure, the effect of ppGpp on $g \operatorname{lgC}$ expression must be limited to steps of translation subsequent to the formation of the first dipeptide bond and prior to the translation of the 64th codon of $g \operatorname{lgC}$, which is the extent of $g \lg \mathrm{C}$ DNA in $\phi\left(g \lg \mathrm{C}^{\prime}-\operatorname{lac} \mathrm{A}\right)$. This seems an unlikely possibility, and, on the basis of substantial experimental evidence that ppGpp affects the transcription of other gene systems (reviewed in [2]), ppGpp probably enhances $g \lg \mathrm{C}$ gene expression at the level of transcription.

The analysis of $g l g \mathrm{C}^{\prime}-' l a c \mathrm{Z}$ expression in spo $\mathrm{T}$ mutants revealed two unexpected responses. The expression of the glycogen biosynthetic enzymes is generally maximal in the early stationary phase [8-12]. However, $\beta$-galactosidase activity from $\phi\left(g \lg \mathrm{C}^{\prime}-\mathrm{l}^{\prime} \mathrm{lac} \mathrm{Z}\right)$ exhibited a peak in the midexponential phase in spoT strains. This peak of activity is likely to reflect fluctuation of the basal ppGPp concentration in these strains, although intracellular levels of ppGPp in these strains have been measured only during the midexponential phase [18]. The second surprising trend in the spo $\mathrm{T}$ strains was the apparent exponential relationship between ppGpp levels and the expression of $\phi\left(g l g \mathrm{C}^{\prime}-\operatorname{lac} \mathrm{Z}\right)$. This relationship appears to be the inverse of that observed for the activity of the rrnA P1 promoter in these strains, which showed an inverse exponential relationship to the doubling times and to ppGpp levels [18]. The precise explanation for these exponential responses awaits rigorous biochemical understanding of the mechanism of ppGpp in these systems. There is mounting evidence that ppGpp may play an important role in general growth rate regulation in addition to its well-established involve- ment in stringent response $[1,2$, and references therein]. This is consistent with the observation that glycogen biosynthesis varies according to the growth rate of the culture [9] and offers a potential mechanism for the regulation.

These studies have further defined the properties of the glycogen excess mutant AC70R1, which was recently shown to positively affect transcription of $g \operatorname{lgC}[16]$. It appears that the expression of chromosome-encoded lac $\mathrm{Z}$ is not significantly altered in AC70R1. Therefore, glgQ probably does not reside in either the catabolite repression or the stringent response regulatory systems, which regulate the expression of native lac $Z[15,16]$. This suggests that a third independent regulatory system controls $g l g$ gene expression.

On the basis of the limited amount of glg DNA that was used in constructing $\phi\left(g l g \mathrm{C}^{\prime}-{ }^{\prime} l a c \mathrm{Z}\right)$, cisacting sites required for cAMP, ppGpp, and $g \lg \mathrm{Q}$ effects are now known to reside within $0.5 \mathrm{~Kb}$ of the glgC transitional start site. Previous studies mapped 5 termini of four discrete transcripts within this region [15]. It is now of interest to determine which of these transcripts respond to cAMP and/or ppGpp. The transcript proximal to the $g \lg \mathrm{C}$ coding region was present in high levels in AC70R 1 (25-fold higher than in $E$. coli B). However, the site of the $g \lg \mathrm{Q}$ mutation and the nature of the factor(s) altered by this mutation are not known, presenting an important challenge for further investigation.

\section{ACKNOWLEDGMENTS}

We wish to thank Michael Cashel (National Institutes of Health) for providing the spoT strains before their construction and characterization had been published. Mathew C. Lorence (University of Texas Health Science Center at Dallas) provided strain MCL22 and information on its use in maxicell analysis. We are grateful to Alicia Gardiol for providing MBM7060 and pMLB1034 and for helpful discussions. We also wish to thank Judith Preiss for preparing the figures. 


\section{Literature Cited}

1. Baracchini $E$, Bremer $H$ (1988) Stringent and growth control of rRNA synthesis in Escherichia coli are both mediated by ppGPp. J Biol Chem 263:2597-2602

2. Cashel M, Rudd KE (1987) The stringent response. In: Ingraham JL, Low KB, Magasanik B, Schaechter M, Umbarger E (eds) Escherichia coli and Salmonella typhimurium: cellular and molecular biology, Vol. 1. Washington, DC: American Society for Microbiology

3. Guerinot L, Chelm BK (1984) Isolation and expression of the Bradyrhizobium japonicum adenylate cyclase gene (cya) in Escherichia coli. J Bacteriol 159:1068-1071

4. Laemmli UK (1970) Cleavage of structural proteins during the assembly of the head of bacteriophage T4. Nature 227:680-685

5. Lorence MC, Alcorn JL, Rupter CS (1985) Construction of an improved maxicell strain for the identification of recombinant plasmid encoded proteins. In: Hollaender A (ed) Plasmids in bacteria, Basic life sciences, vol.30. pp 955

6. Maniatis T, Fritsch EF, Sambrook J (1982) Molecular cloning, a laboratory manual. Cold Spring Harbor, NY: Cold Spring Harbor Laboratory

7. Miller JH (1972) Experiments in molecular genetics. Cold Spring Harbor, NY: Cold Spring Harbor Laboratory

8. Okita TW, Rodriguez RL, Preiss J (1981) Biosynthesis of bacterial glycogen. Cloning of the glycogen biosynthetic enzyme structural genes. J Biol Chem 256:6944-6952

9. Preiss J (1984) Bacterial glycogen biosynthesis and its regulation. Annu Rev Microbiol 38:410-458

10. Preiss J, Romeo T (1989) Physiology, biochemistry and genetics of bacterial glycogen synthesis. Adv Microb Physiol $30: 183-238$
11. Preiss J, Walsh DA (1981) The comparative biochemistry of glycogen and starch. Biol Carbohydr 1:199-314

12. Preiss J, Yung S-G, Baecker PA (1983) Regulation of bacterial glycogen biosynthesis. Mol Cell Biochem 57:61-80

13. Primakoff $P$ (1981) In vivo role of the rel $\mathrm{A}^{+}$gene in the regulation of the lac operon. J Bacteriol 145:410-416

14. Primakoff P, Artz SW (1979) Positive control of lac operon expression in vitro by guanosine $5^{\prime}$-diphosphate $3{ }^{\prime}$-diphosphate. Proc Natl Acad Sci USA 76:1726-1730

15. Romeo T, Preiss J (1989) Genetic regulation of glycogen biosynthesis in Escherichia coli: in vitro effects of cyclic AMP and guanosine 5'-diphosphate $3^{\prime}$-diphosphate and analysis of in vivo transcripts. J Bacteriol 171:2773-2782

16. Romeo T, Kumar A. Preiss J (1988) Analysis of the Escherichia coli glycogen gene cluster suggests that catabolic enzymes are encoded among the biosynthetic genes. Gene $70: 363-376$

17. Sancar A, Hack AM, Rupp DW (1979) Simple method for identification of plasmid-coded proteins. J Bacteriol 137 : 692-693

18. Sarubbi E, Rudd KE, Cashel M (1988) Basal ppGpp level adjustment shown by new spoT mutants affect steady state growth rates and rrnA ribosomal promoter regulation in $E s c h$ erichia coli. Mol Gen Genet 213:214-222

19. Silhavy TJ, Berman ML, Enquist LW (1984) Experiments with gene fusions. Cold Spring Harbor, New York, Cold Spring Harbor Laboratory

20. Urbanowski J, Leung P, Weissbach H, Preiss J (1983) The in vitro expression of the gene for Escherichia coli ADP glucose pyrophosphorylase is stimulated by cyclic AMP and cyclic AMP receptor protein. J Biol Chem 258:27822784 